\title{
The potential of Asystasia intrusa weed of Acanthaceae family as a cover crop in oil palm plantations
}

\author{
HALUS SATRIAWAN", ZAHRUL FUADY, ERNAWITA \\ Department of Agrotechnology, Faculty of Agriculture, Universitas Almuslim. Jl. Almuslim No. 37, Matang Glumpang Dua, Peusangan, Bireuen 24261, \\ Aceh, Indonesia. Tel.: +62-644-442166, "email: satriawan_80@yahoo.co.id
}

Manuscript received: 24 September 2020. Revision accepted: 22 November 2020

\begin{abstract}
Satriawan H, Fuady Z, Ernawita. 2020. The potential of Asystasia intrusa weed as a cover crop in oil palm plantations. Biodiversitas 21: 5710-5717. Weeds generally found in oil palm plantations, one of which is dominant is Asystasia intrusa. This weed has begun to be used as a cover crop on oil palm land because it is assumed to have a beneficial effect. The purpose of this research is to explore the potential of Asystasia intrusa in growing as a cover crop on oil palm plantations. The experimental arrangement used was split-plot design. Oil palm plan's ages were used as the main plot, while the spacing plant (Asystasia intrusa) as the subplots. Experiments were done in triplicate. The results showed that Asystasia intrusa has the potential to be used as a cover crop in oil palm plantations, since it meets several requirements, such as quickly covering the land (12 WAP), fast decomposing (30-60 days), tolerance to shade. This was indicated by the growth percentage of $97.56 \%$, containing nutrients $\mathrm{N}(1.65-1.77 \%), \mathrm{P}(0.29 \%)$, and $\mathrm{K}(4.6-4.97 \%)$, as biomass $(0.9 \mathrm{t} \mathrm{C} / \mathrm{ha} /$ year $)$ and soil carbon stocks $(39.52-41.16 \mathrm{t} / \mathrm{ha} /$ year). The studied weed also has the ability to increase soil carbon stock up to $119 \%$.
\end{abstract}

Keywords: Asystasia intrusa, biomass, carbon stock, cover crops, multi-age oil palm plantations, weed management

\section{INTRODUCTION}

The oil palm is recorded as the largest source of foreign exchange in Indonesia with a value of $\$ 14.7$ billion in 2016, which then increased to $\$ 18.23$ billion in 2018 (BPS 2018). These were obtained from 9 million ha of oil palm plantation area in 2010 (Putra et al. 2012), which then increased to 12.3 million ha with CPO production of 35.3 million tons (Directorate General of Estate Crops 2017). In Aceh Province, the area of oil palm plantation was 393,230 ha, with a proportion of $50.41 \%$ small and $49.59 \%$ private holder plantations (BKPM 2017).

In general, oil palm plantations have nuisance plants called weeds. Satriawan and Fuady (2019) stated that the most common weed species found in oil palm plantations is Asystasia intrusa. The weeds belong to the same family as Asystasia gangetica (L.) T. Anderson. A. gangetica serves as cover plant in oil palm land surface since it can improve the soil capacity to hold water (Yahya, 2010). This is in accordance with the characteristics of its root fibers, which can increase soil pore space, especially the subsoil which affects groundwater storage. Thus, the presence of Asystasia weeds which serve as oil palm land cover, decreases the risks of water shortage in the dry season. Thus, the presence of Asystasia weeds serving as oil palm land cover, minimizing water shortage in the dry season.

A. gangetica, with proper management, can be used as a cover crop in mature oil palm plantations. However, its advantages include the ability to grow well in soils with low fertility, shade tolerance (Samedani et al. 2013), and its capacity of rapid growth at a shade level of $90 \%$ (Asbur et al. 2016). The use of A. gangetica as cover crop has previously reported before (Adetula 2004), and it has been reported to contain several nutrients, such as $\mathrm{N}, \mathrm{P}, \mathrm{K}, \mathrm{Ca}$, $\mathrm{Mg}, \mathrm{Fe}, \mathrm{Zn}$ in plant tissue (Odharva et al. 2007). Furthermore, it is used as green manure for peanut cultivation (Junedi 2014). The results showed that $A$. gangetica was able to increase $43.7 \% \mathrm{~N}, 112.5 \% \mathrm{P}_{2} \mathrm{O}_{5}$, and $162.6 \% \mathrm{~K}_{2} \mathrm{O}$ nutrient contents in the soil (Asbur et al. 2015). The ability of A. gangetica to increase the stability and percent of soil aggregates formed in laboratory-scale also has been reported (Junedi et al. 2015).

The use of certain weed groups as cover crops needs to meet several conditions, such as the ability to propagated using simple techniques, rapid growth to cover the land in a short time, produce lots of leaves and branches, grow well in soil conditions with low fertility levels, easily adapt to the environment without competing in absorbing nutrients with the parent plants (Department of Agriculture 2013), produce high biomass to increase soil organic matter through the stem, twig, and leaf litter (Satriawan and Fuady 2014), increase nitrogen supply, maintain nutrient balance, and improve soil structure (Kruidhof et al. 2009). Therefore, the present study was carried out to evaluate the potency of Asystasia intrusa grows as cover crop in oil palm plantation.

\section{MATERIALS AND METHODS}

The experiments were carried out in Almuslim University, Bireun, Indonesia and the community field oil palm plantations planted in 2012 (8 years old), 2013 (7

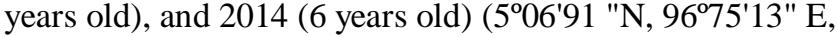


150-200 m a.s.1.), South Peusangan subdistrict, Bireuen Regency, Aceh, Indonesia. The dry weight observation, the analysis of plant tissue and soil chemical properties were carried out at the Almuslim University Integrated Agriculture Laboratory, Bireun, Indonesia. The experimental arrangement used a split-plot design, i.e., the oil palm plants' ages were used on the main plot, while the spacing strategy of Asystasia intrusa was utilized on the subplots. The main consisted of 8,7 , and 6 years plants, while the subplots featured the spacing strategies of $10 \times 10$ $\mathrm{cm}, 20 \times 20 \mathrm{~cm}$, and $30 \times 30 \mathrm{~cm}$, and each treatment was repeated 3 times.

\section{Implementation}

Before planting Asystasia intrusa, the soil was turned over in the tillage layer about $20 \mathrm{~cm}$ above, then harrowed, and leveled with a hoe, this step was carried out 2 weeks before planting. After the soil cultivation was completed, experimental plots were made with a size of $2.5 \times 2 \mathrm{~m}$. Then, the Asystasia intrusa were planted between rows of oil palms using stem cuttings of $15 \mathrm{~cm}$ or two segments, and planted according to the spacing treatment.

\section{Parameter}

The parameters observed were: (i) the growth percentage carried out on 4,8 , and 12 weeks after planting (WAP). (ii) The land coverage percentage carried out by calculating the ability of Asystasia intrusa to spread across the soil surface at 4,8 , and 12 WAP using the $0.5 \mathrm{~m} \times 0.5$ $\mathrm{m}$ square method, which had small holes with a size of 10 $\mathrm{cm} \times 10 \mathrm{~cm}$ to represent the area covered, then calculated using the equation as follows: $\% \mathrm{KPT}=\mathrm{A} / \mathrm{B} \times 100 \%$, where $\mathrm{A}=$ number of holes covered by Asystasia intrusa; $\mathrm{B}$ $=$ the total number of holes. (iii) The plant height $(\mathrm{cm})$ from the age of 2-20 WAP. 4) The number of branches per plant from the age of 8-20 WAP. 5) The number of leaves per plant. 6) Measurement of the total leaf area per plant $\left(\mathrm{cm}^{2}\right)$ using the gravimetric method were conducted as follows: (i) leaf patterns (leaf replicas) were drawn on a plain paper; (ii) the replica of the leaf was weighed using analytical scales; (iii) make $10 \mathrm{~cm} \times 10 \mathrm{~cm}$ paper pieces, then weigh them; (iv) calculate the leaf area using the formula: Leaf area $=($ weight of leaf replica/paper weight $10 \mathrm{x} 10 \mathrm{~cm}) \mathrm{x}$ $100 \mathrm{~cm}^{2} .7$ ) The leaf area index, using the formula: ( (total leaf area $*$ number of leaves)/number of leaves)/100. 8) The dry weight $(\mathrm{g})$ obtained from all plant parts that had been dried using an oven at $80^{\circ} \mathrm{C}$ for 48 hours. The dry weights were measured from $1 \mathrm{~m}$ x $1 \mathrm{~m}$ sample plots, for example, the dry weight per experimental plot was $100 \mathrm{~g} \times$ $5 \mathrm{~m}^{2}=1000 \mathrm{~g} /$ plot.

The decomposition rate is calculated from the depreciation of the weight of the decomposed plant material in one unit of time using the equation: $R=\left(\mathrm{W}_{0^{-}}\right.$ $\left.\mathrm{W}_{\mathrm{t}}\right) / \mathrm{t}$, where: $\mathrm{R}=$ decomposition rate $(\mathrm{g} /$ day $), \mathrm{W}_{0}=$ initial biomass dry weight $(\mathrm{g}), \mathrm{W}_{\mathrm{t}}=$ dry weight of biomass after observation time $\mathrm{t}(\mathrm{g}), \mathrm{t}=$ time of observation (days). Then converted to units of $\mathrm{kg} / \mathrm{ha}$ to determine the total biomass weight of Asystasia intrusa in the oil palm plantation.
Analysis of C-organic, N, P and $\mathrm{K}$ content in tissue plants was carried out by the wet destruction analysis method according to the technical guidelines of the Indonesian Soil Research Institute. Furthermore, the amount of carbon stored from the biomass was estimated using the equation as follows: $\mathrm{C}=$ biomass $(\mathrm{kg} / \mathrm{ha}) \times$ plant $\mathrm{C}$ content. The soil carbon stock was calculated using the equation (Shofiyati et al. 2010) as follows: $\mathrm{CStok}=\mathrm{BD} \times \mathrm{Corg} \times \mathrm{D} \times \mathrm{A}$, where: Cstok $=$ soil carbon stock $(\mathrm{t}$ ha- 1$), \mathrm{BD}=$ soil bulk density $\left(\mathrm{kg} / \mathrm{m}^{3}\right)$, Corg $=$ soil organic $\mathrm{C}$ content $(\%), \mathrm{D}=$ thickness of soil layer (m), A = land area (ha).

\section{RESULTS AND DISCUSSION}

\section{Growth percentage}

The ANOVA test results on the growth percentage of Asystasia intrusa at all ages of oil palm showed significant differences in all groups of oil palm planting years. This showed that Asystasia intrusa was able to grow in low and high shade conditions.

Table 1 showed that Asystasia intrusa met the requirements as a cover crop, due to its high development rate, at 4 WAP it had produced a growth percentage of 60$71 \%$ in oil palm stands aged 8 and 7 years, and 59-63\% aged 6 years. Furthermore, the growth percentage of Asystasia intrusa with a spacing of $30 \times 30 \mathrm{~cm}$ was significantly different from that of $10 \times 10 \mathrm{~cm}$ and $20 \times 20$ $\mathrm{cm}$. On 8year old stands, the treatment at the spacing of 10 $\times 10 \mathrm{~cm}, 20 \times 20 \mathrm{~cm}$, and $30 \times 30 \mathrm{~cm}$ produced increases of $23.53 \%, 25.38 \%$, and $28.91 \%$, respectively. The trend of increasing growth rate also occurred in 2013 and 2014 stands for all spacing with a growth percentage of 9.54$15.44 \%$. Further test analysis also showed a significant difference in the growth percentage, where the spacing of $30 \times 30 \mathrm{~cm}$ at all planting ages of oil palm produced the highest growth.

Table 1. Growth percentage of Asystasia intrusa under oil palm stands

\begin{tabular}{ccccc}
\hline Observation & Spacing of & \multicolumn{3}{c}{ Age of oil palm (years) } \\
\cline { 3 - 5 } time & $\begin{array}{c}\text { A. } \text { intrusa }(\mathbf{c m}) \\
\text { 4 WAP }\end{array}$ & $\mathbf{8}$ & $\mathbf{7}$ & $\mathbf{6}$ \\
\hline & $10 \times 10$ & $65.02^{\mathrm{bA}}$ & $62.75^{\mathrm{aA}}$ & $59.38^{\mathrm{aA}}$ \\
& $20 \times 20$ & $67.13^{\mathrm{bA}}$ & $65.89^{\mathrm{bB}}$ & $61.22^{\mathrm{aAB}}$ \\
& $30 \times 30$ & $71.45^{\mathrm{bB}}$ & $70.34^{\mathrm{bC}}$ & $63.79^{\mathrm{aB}}$ \\
& $10 \times 10$ & $80.32^{\mathrm{bA}}$ & $70.29^{\mathrm{aA}}$ & $68.55^{\mathrm{aA}}$ \\
& $20 \times 20$ & $84.17^{\mathrm{cB}}$ & $73.67^{\mathrm{bB}}$ & $67.21^{\mathrm{aA}}$ \\
& $30 \times 30$ & $92.11^{\mathrm{cC}}$ & $79.77^{\mathrm{bC}}$ & $69.88^{\mathrm{aA}}$ \\
& $10 \times 10$ & $93.44^{\mathrm{cA}}$ & $86.33^{\mathrm{bA}}$ & $79.25^{\mathrm{aA}}$ \\
& $20 \times 20$ & $95.1^{\mathrm{cAB}}$ & $85.99^{\mathrm{bA}}$ & $80.11^{\mathrm{aA}}$ \\
& $30 \times 30$ & $97.56^{\mathrm{bB}}$ & $92.45^{\mathrm{aB}}$ & $90.23^{\mathrm{aB}}$ \\
\hline
\end{tabular}

Note: the numbers followed by the same letter notation in the same column and row are not significantly different on the 5\% LSD test. Lowercase notation is read horizontally, uppercase notation is read vertically. (WAP=weeks after planting. $\mathrm{LSD}=$ least significant difference). 
The greater development of Asystasia intrusa in the 30 $\times 30 \mathrm{~cm}$ spacing compared to other treatments at all planting years was due to the wider range of growth factors in the initial stages, such as nutrients, water, light, and air. This condition showed that at closer spacing, there was competition in receiving sunlight from the beginning of the planting, affecting the amount of photosynthate produced to be used in root development. When the roots had grown, there was more competition in water extraction. Therefore, competition for sunlight and water affected the shoots' growth.

\section{Land coverage percentage}

The ANOVA test results and the further tests showed that the percentage of Asystasia intrusa planted in oil palm plantations aged 8,7 , and 6 years were significantly different, due to the treatment at each spacing. This showed that the cover crop percentage was influenced by the differences in spacing, not by the age of oil palms (Table 2). The initial stage of Asystasia intrusa growth did not show satisfying land cover capability, both in 2012, 2013, and 2014 planting years. The land cover percentage at 4 WAP in these years was around $10.93-29.23 \%$. The highest cover percentage was produced by the spacing of $10 \times 10$ $\mathrm{cm}$ in oil palm stands in 2012 planting year. A significant increase in the land cover percentage occurred at the age of $8 \mathrm{WAP}$, while in 2013 the spacing of $30 \times 30 \mathrm{~cm}$ and $20 \times$ $20 \mathrm{~cm}$ produced the highest increase of 83.80 and $62.73 \%$, with an initial land cover of $10.93 \%$. The observations at the age of 8 WAP showed that the land cover percentage of Asystasia intrusa at all spacing in all oil palm planting ages reached a maximum of $>100 \%$. The result also showed that the highest land cover percentage was produced at a spacing of $10 \mathrm{~cm} \times 10 \mathrm{~cm}$ in all oil palm planting years.

The greater cover percentage of Asystasia intrusa in the $10 \times 10 \mathrm{~cm}$ spacing treatment was related to a large number of individuals per unit area. This was related to the canopy produced with a larger population, covering the empty space between the plants. However, the land cover percentage of Asystasia intrusa was still much lower than that of Arachis pintoi, which reached $100 \%$ at the age of 12 WAP (Purba and Rahutomo 2000; Evrizal 2003), Nephrolepis bisserata which covered $94.16 \%$ of the land surface (Ariyanti et al. 2016), and the Asystasia gangetica which reached $100 \%$ (Asbur et al. 2018).

The land cover percentage was an indicator that showed the speed of plants in covering the surface of cultivated land (Asbur et al. 2018). Alonso-Ayuso et al. (2014; 2018) stated that the existence of ground cover crops influenced the increasing soil moisture and suppressing the weed growths that were detrimental to staple crops. However, the speed of land cover crop was strongly influenced by the growth percentage, plant height/length, number of branches, and leaves (Suryana et al. 2019; Kaye et al. 2019).

\section{Plant height}

The height was the common indicator for studying plant growth, since they were easier to observe. For plant height, observations were made at the age of 2-WAP. The further analysis at 6 years showed that Asystasia intrusa spacing had an effect on plant height at 4, 8, 12, 16, and $20 \mathrm{WAP}$, while plant height at 2 WAP did not produce a significant difference. The uniform plant height patterns were produced at 7 and 8 years, while all spacing had a significant effect on the growth of Asystasia intrusa. In general, the spacing with the most significant effect was 30 $\mathrm{cm} \times 30 \mathrm{~cm}$ (Table 3 ).

The height increase of Asystasia intrusa showed that a wider spacing, the competition between individual plants to access light, nutrients, and water, optimally affected plant development (Rusdiana et al. 2000). The results indicated that A. gangetica served as shade-tolerant plant, since there was no etiolation even at a tighter spacing. Based on Table 2 , there was no significant difference in plant height.

Table 2. Land cover percentage of Asystasia intrusa under oil palm stands

\begin{tabular}{|c|c|c|c|c|}
\hline \multirow{2}{*}{$\begin{array}{c}\text { Observation } \\
\text { time }\end{array}$} & \multirow{2}{*}{$\begin{array}{c}\text { Spacing of } \\
\text { A. intrusa }(\mathrm{cm})\end{array}$} & \multicolumn{3}{|c|}{ Age of oil palm (years) } \\
\hline & & 8 & 7 & 6 \\
\hline \multirow[t]{3}{*}{$4 \mathrm{WAP}$} & $10 \times 10$ & $29.23^{\mathrm{cC}}$ & $23.33^{\mathrm{aC}}$ & $21.1^{\mathrm{aC}}$ \\
\hline & $20 \times 20$ & $18.99^{\mathrm{bB}}$ & $15.51^{\mathrm{aB}}$ & $14.34^{\mathrm{aB}}$ \\
\hline & $30 \times 30$ & $15.63^{\mathrm{bA}}$ & $10.93^{\mathrm{aA}}$ & $11.67^{\mathrm{aA}}$ \\
\hline \multirow[t]{3}{*}{$8 \mathrm{WAP}$} & $10 \times 10$ & $37.41^{\mathrm{bC}}$ & $32.12^{\mathrm{aC}}$ & $30.95^{\mathrm{aC}}$ \\
\hline & $20 \times 20$ & $29.71^{\mathrm{cB}}$ & $25.24^{\mathrm{bB}}$ & $21.02^{\mathrm{aB}}$ \\
\hline & $30 \times 30$ & $23.45^{\mathrm{cA}}$ & $20.09^{\mathrm{bA}}$ & $16.82^{\mathrm{aA}}$ \\
\hline \multirow[t]{3}{*}{12 WAP } & $10 \times 10$ & $82.59^{\mathrm{cC}}$ & $78.89^{\mathrm{bC}}$ & $74.67^{\mathrm{aC}}$ \\
\hline & $20 \times 20$ & $66.2^{\mathrm{bB}}$ & $62.1^{\mathrm{aB}}$ & $59.51^{\mathrm{aB}}$ \\
\hline & $30 \times 30$ & $59.76^{\mathrm{cA}}$ & $55.54^{\mathrm{bA}}$ & $51.79^{\mathrm{aA}}$ \\
\hline
\end{tabular}

Note: the numbers followed by the same letter notation in the same column and row are not significantly different on the 5\% LSD test. Lowercase notation is read horizontally, uppercase notation is read vertically. (WAP=weeks after planting. LSD= least significant difference).

Table 3. Height growth of Asystasia intrusa under oil palm stands

\begin{tabular}{ccccc}
\hline $\begin{array}{c}\text { Observation } \\
\text { time }\end{array}$ & $\begin{array}{c}\text { Spacing of } \\
\text { A. } \text { intrusa }(\mathbf{c m})\end{array}$ & \multicolumn{3}{c}{ Age of oil palm (years) } \\
\cline { 3 - 5 } $2 \mathrm{~W}$ & $\mathbf{8}$ & $\mathbf{7}$ & $\mathbf{6}$ \\
\hline & $10 \times 10$ & $16.76^{\mathrm{aA}}$ & $16.11^{\mathrm{aA}}$ & $15.3^{\mathrm{aA}}$ \\
& $20 \times 20$ & $19.55^{\mathrm{bB}}$ & $17.87^{\mathrm{aA}}$ & $17.21^{\mathrm{aA}}$ \\
$4 \mathrm{WAP}$ & $30 \times 30$ & $22.98^{\mathrm{bC}}$ & $21.12^{\mathrm{aB}}$ & $20.34^{\mathrm{aB}}$ \\
& $10 \times 10$ & $20.05^{\mathrm{bA}}$ & $19.22^{\mathrm{bA}}$ & $16.79^{\mathrm{aA}}$ \\
& $20 \times 20$ & $22.13^{\mathrm{bA}}$ & $20.65^{\mathrm{aAB}}$ & $19.13^{\mathrm{aB}}$ \\
& $30 \times 30$ & $25.12^{\mathrm{bB}}$ & $22.97^{\mathrm{aB}}$ & $22.86^{\mathrm{aC}}$ \\
& $10 \times 10$ & $24.22^{\mathrm{bA}}$ & $21.33^{\mathrm{aA}}$ & $20.26^{\mathrm{aA}}$ \\
& $20 \times 20$ & $26.89^{\mathrm{bB}}$ & $23.99^{\mathrm{aA}}$ & $23.11^{\mathrm{aB}}$ \\
& $30 \times 30$ & $29.06^{\mathrm{bC}}$ & $27.85^{\mathrm{aB}}$ & $26.13^{\mathrm{aC}}$ \\
& $10 \times 10$ & $35.01^{\mathrm{bA}}$ & $33.29^{\mathrm{aA}}$ & $31.57^{\mathrm{aA}}$ \\
& $20 \times 20$ & $39.33^{\mathrm{bB}}$ & $36.78^{\mathrm{aB}}$ & $35.24^{\mathrm{aB}}$ \\
& $30 \times 30$ & $40.59^{\mathrm{aB}}$ & $39.55^{\mathrm{aC}}$ & $39.61^{\mathrm{aC}}$ \\
& $10 \times 10$ & $46.67^{\mathrm{bA}}$ & $43.1^{\mathrm{aA}}$ & $42.88^{\mathrm{aA}}$ \\
& $20 \times 20$ & $50.53^{\mathrm{bB}}$ & $48.23^{\mathrm{aB}}$ & $46.37^{\mathrm{aB}}$ \\
& $30 \times 30$ & $59.79^{\mathrm{bC}}$ & $53.41^{\mathrm{aC}}$ & $51.02^{\mathrm{aC}}$ \\
& $10 \times 10$ & $56.82^{\mathrm{bA}}$ & $55.77^{\mathrm{abA}}$ & $53.99^{\mathrm{aA}}$ \\
& $20 \times 20$ & $60.13^{\mathrm{aB}}$ & $58.53^{\mathrm{aB}}$ & $58.22^{\mathrm{aB}}$ \\
& $30 \times 30$ & $65.34^{\mathrm{bC}}$ & $64.19^{\mathrm{abC}}$ & $63.76^{\mathrm{aC}}$ \\
\hline
\end{tabular}

Note: the numbers followed by the same letter notation in the same column and row are not significantly different on the 5\% LSD test. Lowercase notation is read horizontally, uppercase notation is read vertically. (WAP=weeks after planting. $\mathrm{LSD}=$ least significant difference) 


\section{Number of branches}

The spacing setting had a significant effect on the growth of Asystasia intrusa branches, both in oil palm plantations at the ages of 6,7 , and 8 years (Table 4). The spacing of $30 \times 30 \mathrm{~cm}$ produced a higher number of branches compared to those of $10 \mathrm{~cm} \times 10 \mathrm{~cm}$ and $20 \mathrm{~cm} \times$ $20 \mathrm{~cm}$ at all ages.

Number of Asystasia intrusa branches per plant increased with a rise in the plant age (Table 4). At 2-12 WAP, the increase in the number of Asystasia intrusa branches per plant at all spacing and age was almost the same. However, after 16-20 WAP, it started showing differences. This might be due to tight spacing, the competition for light, water, and nutrients were can not be avoided. Therefore the plant growth start to inhibited, while at sparse spacing, the competitions were less, thus, making plant grow better.

\section{Number of leaves, total leaf area and leaf area index}

In plant analysis, the leaf parameter was very important to be observed, since it related to the overall growth. The leaf organ was the site for photosynthesis which produced photosynthate for the needs of other plant tissues (Asbur et al. 2018). The variance analysis showed that the number and total area of Asystasia intrusa leaves were significantly different, due to the spacing at all ages, where $30 \times 30 \mathrm{~cm}$ produced the largest number of leaves. The number and total area of Asystasia intrusa leaves in 7-year-old oil palm plantations were greater and wider than that of 6 and 8 year-old. This showed that Asystasia intrusa had the ability to grow in highly shaded conditions, even when their number and total area of leaves were less (Table 5).

\section{Dry weight and decomposition rate}

The dry weight was determined from the root and shoot, which were the indicator for plant growth. Dry weight closely related to plant's nutrient absorption and growth performance. The greater dry weight recorded indicating optimum nutrient absorption and normal plant organ growth (Fageira and Moreira, 2011). The analysis of the dry weight of Asystasia intrusa per treatment plot was shown in Table 6. The ANOVA results showed that the spacing had a significant effect on the dry weight of Asystasia intrusa at the ages of 4,12 , and $20 \mathrm{WAP}$ on 6, 7, and 8-year-old oil palm stands. The spacing of $10 \mathrm{~cm} \times 10$ $\mathrm{cm}$ produced a higher dry weight per experimental plot than that of $20 \mathrm{~cm} \times 20 \mathrm{~cm}$ and $30 \times 30 \mathrm{~cm}$. The high dry weight of Asystasia intrusa per experimental plot at a spacing of $10 \times 10 \mathrm{~cm}$ was caused by the high number and area of leaves (Table 5). Haryantini and Santoso (2001) stated that plants with better leaf area have higher ability to photosynthesize optimally, due to the wider surface area receiving sunlight. Therefore, the photosynthesis results in the form of carbohydrates affected the increase in cell size, i.e., the additional dry weight.

The decomposition rate of Asystasia intrusa was influenced by the condition of oil palm stands at each age. In this case, the highest and fastest decomposition was found in 6 , followed by 7 and 8 -year-old oil palm stands. In this study, Asystasia intrusa was not easily decomposed. In
30 days, only $73 \%$ of the total biomass disintegrated at a rate of $1.22 \%$ per day. In 60 days, as much as $94.6 \%$ of its biomass was decomposed. The lower results were obtained in the stands aged 7 and 8 years, namely $91.4 \%$ and $85.6 \%$ (Table 7). This indicated that the increase in oil palm age inhibited the decomposition rate of plant litter underneath. This phenomenon was interesting when related to the sustainability of organic deposits in maintaining soil fertility. The rate of decomposition of Asystasia intrusa is lower than that of Nephrolepsis bisserata (3.2\%) but the total disintegration after 60 days were similar (Ariyanti et al. 2014; 2015).

Table 4. Number of Asystasia intrusa branches under oil palm stands

\begin{tabular}{|c|c|c|c|c|}
\hline \multirow{2}{*}{$\begin{array}{c}\text { Observation } \\
\text { time }\end{array}$} & \multirow{2}{*}{$\begin{array}{c}\text { Spacing of } \\
\text { A. intrusa }(\mathrm{cm})\end{array}$} & \multicolumn{3}{|c|}{ Age of oil palm (years) } \\
\hline & & 8 & 7 & 6 \\
\hline \multirow[t]{3}{*}{8 WAP } & $10 \times 10$ & $3.6^{\mathrm{bA}}$ & $3.5^{\mathrm{bA}}$ & $2.9^{\mathrm{aA}}$ \\
\hline & $20 \times 20$ & $3.8^{\mathrm{bA}}$ & $3.7^{\mathrm{bAB}}$ & $3.3^{\mathrm{aB}}$ \\
\hline & $30 \times 30$ & $4.3^{\mathrm{bB}}$ & $4.1^{\mathrm{bB}}$ & $3.8^{\mathrm{aC}}$ \\
\hline \multirow[t]{3}{*}{$10 \mathrm{WAP}$} & $10 \times 10$ & $4.4^{\mathrm{bA}}$ & $4.4^{\mathrm{bA}}$ & $3.8^{\mathrm{aA}}$ \\
\hline & $20 \times 20$ & $5.3^{\mathrm{bB}}$ & $4.9^{\mathrm{aB}}$ & $4.6^{\mathrm{aB}}$ \\
\hline & $30 \times 30$ & $5.6^{\mathrm{bB}}$ & $5.8^{\mathrm{bC}}$ & $4.9^{\mathrm{aB}}$ \\
\hline \multirow[t]{3}{*}{$12 \mathrm{WAP}$} & $10 \times 10$ & $5.8^{\mathrm{bA}}$ & $5.5^{\mathrm{bA}}$ & $4.4^{\mathrm{aA}}$ \\
\hline & $20 \times 20$ & $7.3^{\mathrm{cB}}$ & $6.6^{\mathrm{bB}}$ & $5.3^{\mathrm{aB}}$ \\
\hline & $30 \times 30$ & $7.8^{\mathrm{cB}}$ & $6.9^{\mathrm{bB}}$ & $5.8^{\mathrm{aB}}$ \\
\hline \multirow[t]{3}{*}{14 WAP } & $10 \times 10$ & $6.9^{\mathrm{bA}}$ & $6.4^{\mathrm{aA}}$ & $6.2^{\mathrm{aA}}$ \\
\hline & $20 \times 20$ & $9.8^{\mathrm{bB}}$ & $8.8^{\mathrm{aB}}$ & $8.5^{\mathrm{aB}}$ \\
\hline & $30 \times 30$ & $10.1^{\mathrm{bB}}$ & $9.1^{\mathrm{aB}}$ & $8.9^{\mathrm{aB}}$ \\
\hline \multirow[t]{3}{*}{$16 \mathrm{WAP}$} & $10 \times 10$ & $9.2^{\mathrm{bA}}$ & $8.9^{\mathrm{abA}}$ & $8.6^{\mathrm{aA}}$ \\
\hline & $20 \times 20$ & $12.8^{\mathrm{bB}}$ & $10.6^{\mathrm{aB}}$ & $10.2^{\mathrm{aB}}$ \\
\hline & $30 \times 30$ & $14.2^{\mathrm{cC}}$ & $11.5^{\mathrm{bB}}$ & $10.8^{\mathrm{aB}}$ \\
\hline \multirow[t]{3}{*}{$18 \mathrm{WAP}$} & $10 \times 10$ & $12.3^{\mathrm{cA}}$ & $11.7^{\mathrm{bA}}$ & $11.2^{\mathrm{aA}}$ \\
\hline & $20 \times 20$ & $16.4^{\mathrm{bB}}$ & $14.2^{\mathrm{aB}}$ & $13.9^{\mathrm{aA}}$ \\
\hline & $30 \times 30$ & $18.7^{\mathrm{cB}}$ & $17.1^{\mathrm{bC}}$ & $16.7^{\mathrm{aB}}$ \\
\hline \multirow[t]{3}{*}{$20 \mathrm{WAP}$} & $10 \times 10$ & $15.2^{\mathrm{bA}}$ & $14.1^{\mathrm{aA}}$ & $13.8^{\mathrm{aA}}$ \\
\hline & $20 \times 20$ & $19.3^{\mathrm{cB}}$ & $17.9^{\mathrm{bB}}$ & $16.9^{\mathrm{aB}}$ \\
\hline & $30 \times 30$ & $22.6^{\mathrm{bC}}$ & $20.2^{\mathrm{aC}}$ & $19.1^{\mathrm{aC}}$ \\
\hline
\end{tabular}

Note: the numbers followed by the same letter notation in the same column and row are not significantly different on the 5\% LSD test. Lowercase notation is read horizontally, uppercase notation is read vertically. (WAP=weeks after planting. $\mathrm{LSD}=$ least significant difference).

Table 5. Number of leaves, total leaf area, and the index of Asystasia intrusa under oil palm stands

\begin{tabular}{ccccc}
\hline Observation & Spacing of & \multicolumn{3}{c}{ Age of oil palm (years) } \\
\cline { 3 - 5 } time & $\boldsymbol{A}$. intrus $\boldsymbol{~}(\mathbf{c m})$ & $\mathbf{8}$ & $\mathbf{7}$ & $\mathbf{6}$ \\
\hline Number of & $10 \times 10$ & $23.4^{\mathrm{aA}}$ & $28.2^{\mathrm{bA}}$ & $30.1^{\mathrm{bA}}$ \\
leaf & $20 \times 20$ & $27.7^{\mathrm{aB}}$ & $38.1^{\mathrm{bB}}$ & $39.6^{\mathrm{bB}}$ \\
(sheet) & $30 \times 30$ & $31.9^{\mathrm{aC}}$ & $45.5^{\mathrm{bC}}$ & $48.2^{\mathrm{cC}}$ \\
Total leaf & $10 \times 10$ & $236.34^{\mathrm{aA}}$ & $309.2^{\mathrm{bA}}$ & $357.28^{\mathrm{cA}}$ \\
area $\left(\mathrm{cm}^{2}\right)$ & $20 \times 20$ & $330.78^{\mathrm{aB}}$ & $489.2^{\mathrm{bB}}$ & $509.26^{\mathrm{bB}}$ \\
& $30 \times 30$ & $408.01^{\mathrm{aC}}$ & $583.31^{\mathrm{bC}}$ & $626.6^{\mathrm{bC}}$ \\
Leaf area & $10 \times 10$ & $2.36^{\mathrm{aB}}$ & $3.09^{\mathrm{bC}}$ & $3.57^{\mathrm{cC}}$ \\
index & $20 \times 20$ & $0.83^{\mathrm{aA}}$ & $1.22^{\mathrm{bB}}$ & $1.27^{\mathrm{bB}}$ \\
& $30 \times 30$ & $0.45^{\mathrm{aA}}$ & $0.65^{\mathrm{bA}}$ & $0.70^{\mathrm{bA}}$ \\
\hline
\end{tabular}

Note: the numbers followed by the same letter notation in the same column and row are not significantly different on the 5\% LSD test. Lowercase notation is read horizontally, uppercase notation is read vertically. LSD: least significant difference 
Table 6. Dry weight of Asystasia intrusa under oil palm stands

\begin{tabular}{ccccc}
\hline Observation & Spacing of & \multicolumn{3}{c}{ Age of oil palm (years) } \\
\cline { 3 - 5 } time & A. intrusa $(\mathbf{c m})$ & $\mathbf{8}$ & $\mathbf{7}$ & $\mathbf{6}$ \\
\hline $4 \mathrm{WAP}$ & $10 \times 10$ & $123.2^{\mathrm{aC}}$ & $138.9^{\mathrm{bB}}$ & $201.2^{\mathrm{cB}}$ \\
& $20 \times 20$ & $101.1^{\mathrm{aB}}$ & $118.2^{\mathrm{bA}}$ & $149.1^{\mathrm{cA}}$ \\
& $30 \times 30$ & $99.78^{\mathrm{aA}}$ & $105.6^{\mathrm{aA}}$ & $128.3^{\mathrm{bA}}$ \\
$8 \mathrm{WAP}$ & $10 \times 10$ & $636.4^{\mathrm{bB}}$ & $579.7^{\mathrm{aC}}$ & $557.2^{\mathrm{aC}}$ \\
& $20 \times 20$ & $532.8^{\mathrm{cA}}$ & $483.4^{\mathrm{bB}}$ & $409.6^{\mathrm{aB}}$ \\
& $30 \times 30$ & $448.8^{\mathrm{cA}}$ & $381.1^{\mathrm{bA}}$ & $326.6^{\mathrm{aA}}$ \\
$12 \mathrm{WAP}$ & $10 \times 10$ & $982.30^{\mathrm{bC}}$ & $734.10^{\mathrm{aC}}$ & $722.20^{\mathrm{aC}}$ \\
& $20 \times 20$ & $799.40^{\mathrm{bB}}$ & $612.30^{\mathrm{aB}}$ & $620.10^{\mathrm{aB}}$ \\
& $30 \times 30$ & $689.50^{\mathrm{bA}}$ & $521.10^{\mathrm{aA}}$ & $511.60^{\mathrm{aA}}$ \\
\hline
\end{tabular}

Note: the numbers followed by the same letter notation in the same column and row are not significantly different on the 5\% LSD test. Lowercase notation is read horizontally, uppercase notation is read vertically. (WAP=weeks after planting. $\mathrm{LSD}=$ least significant difference)

Furthermore, the biomass weight loss of Asystasia intrusa was greater than the oil palm fronds and other weeds such as Melastoma malabathricum L. Study showed that oil palm fronds and M. malabathricum took 14 months to decomposed with a biomass weight loss of $83.1 \%$ and $87.6 \%$, respectively (Maswar, 2009). Furthermore, the research results of Sulistiyanto et al. (2005) in Central Kalimantan showed that forest biomass in mixed swamp and low pole forest required a longer decomposition time (18 months) than A. gangetica, with weight loss of $34.7 \%$ and $27.6 \%$, respectively. Based on environmental conditions, temperature played an important role as a factor affecting the decomposition rate (Quideau et al. 2001, Heviaa et al. 2003). In this situation, light intensity and air temperature played a higher role than air humidity.

\section{Plant tissue nutrient content and potential carbon stocks}

The ANOVA results on the nutrient content of Asystasia intrusa plant tissue obtained from the roots, stems, and leaves showed that the levels of C-organic, N, P, and $\mathrm{K}$ contents were influenced by plant parts. Our study showed that the highest $\mathrm{C}$-organic was obtained in the roots, while the highest $\mathrm{N}, \mathrm{P}$, and $\mathrm{K}$ content were obtained in the leaves. However, the effect of oil palm stand age was not significantly different (Table 8).
Table 8 showed that Asystasia intrusa in an 8-year-old palm stand had an average C-organic, $\mathrm{N}, \mathrm{P}$, and $\mathrm{K}$ content of $46.3 \%, 1.77 \%, 0.29 \%$, and $4.97 \%$, respectively. In a $7-$ year-old palm stand, it was obtained at $45.6 \%$ C-organic, $1.71 \% \mathrm{~N}, 0.29 \% \mathrm{P}$, and $4.77 \% \mathrm{~K}$. Meanwhile, in a 6-yearold palm stand, the $\mathrm{C}$-organic, $\mathrm{P}$, and $\mathrm{K}$ contents were obtained at $44.1 \%, 0.29 \%$, and $4.6 \%$, respectively. The high levels of $\mathrm{K}$ in the stems and leaves of Asystasia intrusa exceeded that of food plants in general. However, the $\mathrm{K}$ high levels were also found in other weeds, such as Tithonia diversifolia (paitan) with $5.1 \% \mathrm{~K}$ content in its leaves (Hartatik 2007). These results were also higher than the nutrient content of $N$. biserrata (Ariyanti et al. 2016), A. gangetica, P. conjugatum, and A. conyzoides (Asbur et al. 2018).

The C-organic content and the macro-nutrients (N, P, $\mathrm{K})$ in Asystasia intrusa plant tissue showed that this weed had the ability to enrich the soil through litter decomposition (Table 8). According to Landriscini et al. (2019), using ground cover crops was an efficient alternative in producing biomass and nutrient supply to the soil.

Table 8. Nutrient content of Asystasia intrusa plant tissue under oil palm stands

\begin{tabular}{cllll}
\hline \multirow{2}{*}{$\begin{array}{c}\text { Nutrient } \\
(\%)\end{array}$} & Plant organs & \multicolumn{3}{c}{ Age of oil palm (years) } \\
\cline { 3 - 5 } & & \multicolumn{1}{c}{$\mathbf{8}$} & \multicolumn{1}{c}{$\mathbf{7}$} & $\mathbf{6}$ \\
\hline C-Organic & Roots & $50.23^{\mathrm{bC}}$ & $50.01^{\mathrm{bC}}$ & $48.34^{\mathrm{aC}}$ \\
& Stems & $46.13^{\mathrm{bB}}$ & $45.81^{\mathrm{bB}}$ & $43.84^{\mathrm{aB}}$ \\
$\mathrm{N}$ & Leaves & $42.63^{\mathrm{bA}}$ & $41.12^{\mathrm{abA}}$ & $40.04^{\mathrm{aA}}$ \\
& Roots & $1.4^{\mathrm{aA}}$ & $1.38^{\mathrm{aA}}$ & $1.38^{\mathrm{aA}}$ \\
& Stems & $1.8^{\mathrm{aB}}$ & $1.75^{\mathrm{aB}}$ & $1.77^{\mathrm{aB}}$ \\
$\mathrm{P}$ & Leaves & $2.1^{\mathrm{bC}}$ & $2^{\mathrm{abC}}$ & $1.8^{\mathrm{aB}}$ \\
& Roots & $0.23^{\mathrm{aA}}$ & $0.23^{\mathrm{aA}}$ & $0.22^{\mathrm{aA}}$ \\
& Stems & $0.31^{\mathrm{aB}}$ & $0.32^{\mathrm{aB}}$ & $0.33^{\mathrm{aB}}$ \\
$\mathrm{K}$ & Leaves & $0.33^{\mathrm{aB}}$ & $0.32^{\mathrm{aB}}$ & $0.33^{\mathrm{aB}}$ \\
& Roots & $2^{\mathrm{aA}}$ & $1.9^{\mathrm{aA}}$ & $1.8^{\mathrm{aA}}$ \\
& Stems & $5.8^{\mathrm{bB}}$ & $5.6^{\mathrm{abB}}$ & $5.5^{\mathrm{aB}}$ \\
& Leaves & $7.1^{\mathrm{cC}}$ & $6.8^{\mathrm{bC}}$ & $6.5^{\mathrm{aC}}$ \\
\hline
\end{tabular}

Note: the numbers followed by the same letter notation in the same column and row are not significantly different on the 5\% LSD test. Lowercase notation is read horizontally, uppercase notation is read vertically. LSD: least significant difference, C: carbon, N: nitrogen, P: phosphor; K: kalium/potassium

Table 7. Decomposition rate of Asystasia intrusa under oil palm stands

\begin{tabular}{lccccccc}
\hline Age of oil palm & $\begin{array}{c}\text { Initial } \\
\text { weight }(\mathbf{g})\end{array}$ & $\begin{array}{c}\text { Weight of } \\
\mathbf{3 0} \text { days }(\mathbf{g})\end{array}$ & $\begin{array}{c}\text { Weight of } \\
\mathbf{6 0} \text { days }(\mathbf{g})\end{array}$ & $\begin{array}{c}\text { Decomposition } \\
\text { rate of 30 days } \\
(\boldsymbol{\%} / \mathbf{d a y})\end{array}$ & $\begin{array}{c}\text { Decomposition } \\
\text { rate of 60 days } \\
(\% / \text { day })\end{array}$ & $\begin{array}{c}\text { Decomposed } \\
\text { biomass } \\
\text { of 30 days }(\%)\end{array}$ & $\begin{array}{c}\text { Decomposed } \\
\text { biomass } \\
\text { of } \mathbf{6 0} \text { days }(\%)\end{array}$ \\
\hline 8 years & 50 & $20.1^{\mathrm{c}}$ & $7.2^{\mathrm{c}}$ & $1.00^{\mathrm{a}}$ & $0.71^{\mathrm{a}}$ & $59.8^{\mathrm{a}}$ & $85.6^{\mathrm{a}}$ \\
7 years & 50 & $17.3^{\mathrm{b}}$ & $4.3^{\mathrm{b}}$ & $1.09^{\mathrm{a}}$ & $0.76^{\mathrm{b}}$ & $65.4^{\mathrm{b}}$ & $91.4^{\mathrm{b}}$ \\
6 years & 50 & $13.5^{\mathrm{a}}$ & $2.7^{\mathrm{a}}$ & $1.22^{\mathrm{b}}$ & $0.79^{\mathrm{b}}$ & $73^{\mathrm{c}}$ & $94.6^{\mathrm{b}}$ \\
\hline
\end{tabular}

Note: The numbers followed by the same letter were not significantly different in the LSD (Least Significant Difference) test at $\alpha$ 5\%. 
Besides the nutrient content of weeds, such as $N$. biserrata, it was known to contain C-organic, nitrogen, phosphate, and potassium at $35.63 \%, 4.02 \%, 0.27 \%$, and $1.21 \%$, respectively. Furthermore, A. gangetica contained $33.30 \%$ C-organic, $3.14 \%$ nitrogen, $0.22 \%$ phosphate, and $2.41 \%$ potassium. The $P$. conjugatum contained $35.71 \% \mathrm{C}$ organic, $2.61 \%$ nitrogen, $0.31 \%$ phosphate, $1.83 \%$ potassium, while A. conyzoides contained $37.23 \% \mathrm{C}$ organic, $2.49 \%$ nitrogen, $0.18 \%$ phosphate, and $2.12 \%$ potassium. This was different from the results of Ariyanti et al. (2016) in an oil palm plantation in South Lampung, which showed that $N$. biserrata contained $50.70 \%$ Corganic, $1.43 \% \mathrm{~N}, 0.17 \mathrm{P}$, and $1.67 \% \mathrm{~K}$. Similarly, the results of Asbur et al. (2016) in South Lampung oil palm plantations showed that A. gangetica contained $48.90 \%$ Corganic, $1.90 \% \mathrm{~N}, 0.27 \% \mathrm{P}$, and $4.67 \% \mathrm{~K}$. This indicated that the content of organic matter and the plant nutrients in different areas were varied and influenced by various environmental factors in the location where the weeds grew.

The carbon stock was the amount stored in an ecosystem at a certain time in the form of biomass, dead plants, or soil carbon (Agus et al. 2011). The Asystasia intrusa carbon stock was obtained on a $1 \mathrm{~m} \mathrm{x} 1 \mathrm{~m}$ sample plot, from the plant biomass and soil. The carbon stock estimation on a land was obtained from the potential dry weight of biomass growing on it, which composed of $45 \%$ $50 \%$. Therefore the ability of a plant to store carbon (as stock) was estimated from half the total dry weight of its biomass (Brown and Gaston 1996).

Therefore, carbon stock stored by each part of Asystasia intrusa biomass was almost half of the total dry weight (Figure 1). It also means that an increased amount of biomass in a plant rises the carbon stock in an agricultural system. Based on Figure 1, the Asystasia intrusa biomass was able to store 0.6-0.9 tonnes $\mathrm{C} / \mathrm{ha} /$ year in plant tissue. The estimated biomass carbon stock of Asystasia intrusa was very low compared to that of oil palm fronds, $M$. malabatricum, and Cycas sp. Biomass carbon stock recorded in the smallholder plantations in peatland in Aceh was 9.4-12.2 ton/ha/year (Maswar, 2009; Maswar et al.,
2011). While the biomass carbon stock in tropical Asian forests was 40-250 ton/ha (Lasco, 2002).

\section{Soil carbon stocks}

Figure 2 showed that the land with Asystasia intrusa under an 8-year-old palm oil stand was able to increase soil carbon stock by $119 \%, 115 \%$, and $95.65 \%$ at a depth of 0 $10 \mathrm{~cm}, 10-20 \mathrm{~cm}$, and $20-30 \mathrm{~cm}$, respectively. In a 7-yearold oil palm stand, Asystasia intrusa was able to improve soil C organic content by $113 \%, 105.6 \%$, and $104.5 \%$ at a soil depth of $0-10 \mathrm{~cm}, 10-20 \mathrm{~cm}$, and $20-30 \mathrm{~cm}$, respectively. Meanwhile, in a 6-year-old oil palm stand, there was an increase in C organic stock by $105.2 \%$, $101.5 \%$, and $110 \%$ at a depth of $0-10 \mathrm{~cm}, 10-20 \mathrm{~cm}$, and $20-30 \mathrm{~cm}$, respectively. This indicated that the presence of Asystasia intrusa increased carbon stock by almost 2 times for every depth profile. The increased soil carbon stock of Asystasia intrusa was due to the rise $\mathrm{C}$ organic content from $0.5 \%$ at a depth of $0-10 \mathrm{~cm}$ before planting to $1.3 \%$ after cultivating. Furthermore, at a depth of $10-20 \mathrm{~cm}$ and $20-30 \mathrm{~cm}$, it increased from $0.4 \%$ and $0.45 \%$ before planting to $1.2 \%$ and $1.15 \%$ after cultivating. Shofiyati et al. (2010) and Ohkura et al. (2003) stated that soil carbon content was influenced by its physical properties (especially bulk density), and the vegetation type growing on it. Plants stored carbon from photosynthesis process to become the constituent materials of the tissue. However, when leaves, twigs, or the whole plant died, these materials then returned to the soil and decomposed. The decomposition process partially produced $\mathrm{CO}_{2}$ gas, released again into the air, while some were retained in the ground (Robert 2001).

When the soil carbon stock for each depth was added up, the results were respectively $41.16,40.7$, and 39.52 tonnes/ha/year in oil palm stands aged 8, 7, and 6 years. Although this soil carbon stock was quite small, it was still in the same range as those in the tropical forests at the same depth, namely 5-180 tonnes/ha (IPCC, 1997). And also much larger than the carbon stock of oil palm plantations in the Paser Regency, East Kalimantan, which was only 0.1 tonnes/ha (Sugirahayu and Rusdiana 2011).

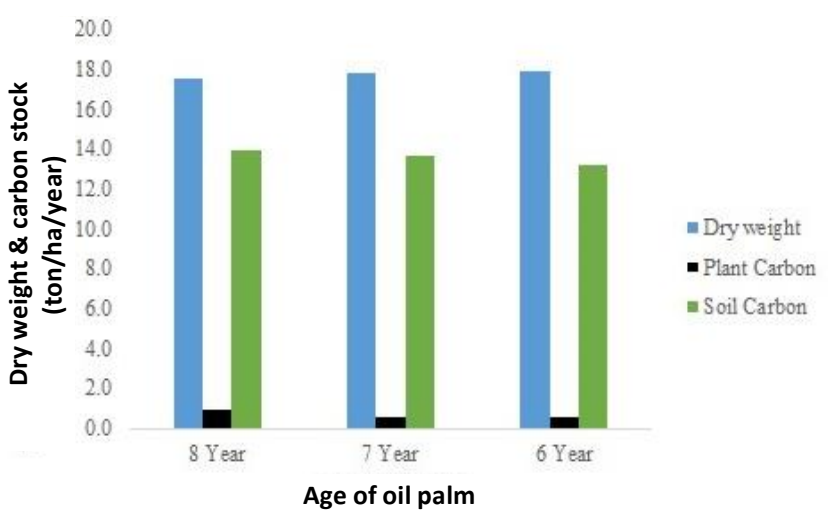

Figure 1. Asystasia intrusa biomass carbon stock

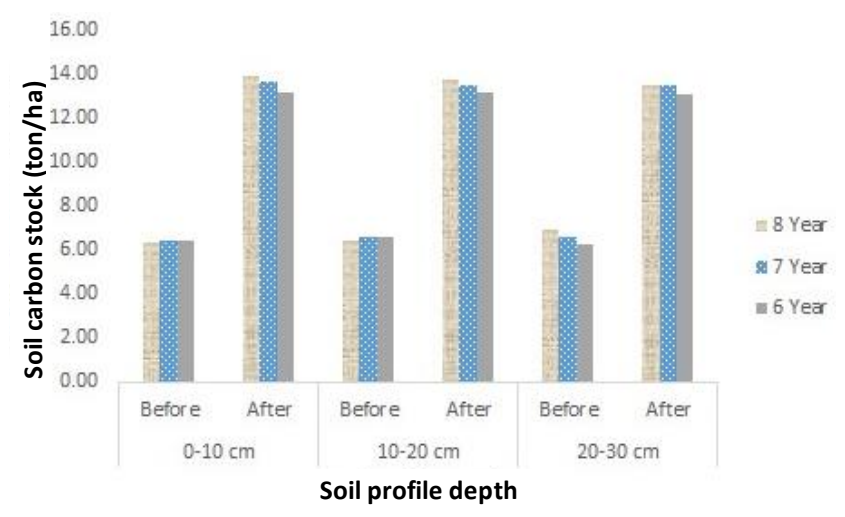

Figure 2. Soil carbon stock under oil palm 
The increased carbon stock under oil palm stands due to Asystasia intrusa improved soil physical and chemical properties, and also increased groundwater stocks. The absolute $\mathrm{C}$ organic content in biomass at a certain time was known as carbon stock (Ulumuddin et al. 2005). Meanwhile, half of the total $\mathrm{CO}_{2}$ was absorbed by plants from the free air entering the soil through the decomposition of plant residues (litter), dead roots, and other organisms (Hikmat 2005; Ruddiman 2007).

In conclusion, Asystasia intrusa has the potential to be used as ground cover crop in oil palm plantations. It met several requirements as ground cover crop, i.e fast growth covering the land (12 WAP), fast decomposition rate (3060 days), tolerant to shade which was indicated by the growth percentage of $97.56 \%$, containing nutrients N (1.65$1.77 \%), \mathrm{P}(0.29 \%)$, and $\mathrm{K}(4.6-4.97 \%)$, as biomass ( 0.9 ton $\mathrm{C} / \mathrm{ha} /$ year) and soil carbon stocks (39.52-41.16 tonnes/ha/year. And also has the ability to increase soil carbon stock up to $119 \%$.

The optimum spacing for planting Asystasia intrusa as ground cover crop in oil palm plantations was $10 \mathrm{~cm} \times 10$ $\mathrm{cm}$ followed by $20 \times 20 \mathrm{~cm}$ and $30 \times 30 \mathrm{~cm}$. Meanwhile, the number of leaves, their area index, and the total leaf area per plant at a spacing of $30 \mathrm{~cm} \mathrm{x} 30 \mathrm{~cm}$ were higher than that of $20 \mathrm{~cm} \mathrm{x} 20 \mathrm{~cm}$ and $10 \mathrm{~cm} \mathrm{x} 10 \mathrm{~cm}$.

\section{ACKNOWLEDGEMENTS}

The authors express the appreciation and gratitude to the Directorate of Research and Community Service Deputy for Research and Technology Strengthening Ministry of Research and Technology/Research and Innovation Agency with LLDIKTI Region XIII Number 235/SP2H/LT/DRPM/2020.

\section{REFERENCES}

Adetula OA. 2004. Asystasia gangetica (L.) Anderson. In: Grubben GJH Denton OA (eds.). PROTA (Plant Resources of Tropical Africa/Ressources végétales de l'Afrique tropicale), Wageningen, Netherlands. www.prota4u.org/search.asp.

Agus F, Hairiah K, Mulyani A. 2011. Pengukuran Cadangan Karbon Tanah Gambut. Petunjuk Praktis. World Agroforestry Centre-ICRAF, SEA Regional Office dan Balai Besar Penelitiandan Pengembangan Sumberdaya Lahan Pertanian (BBSDLP), Bogor. [Indonesian]

Alonso-Ayuso M, Gabriel JL, Quemada M. 2014. The kill date as a management tool for cover cropping success. PLoS One 9 (10): e109587. DOI: 10.1371/journal.pone.0109587.

Alonso-Ayuso, M., J. L. Gabriel, I. García-González, J.P. Del Montea, M. Quemada. 2018. Weeddensity and diversity in a long-term cover cropexperiment background. Crop Protect 112: 103-111. DOI: 10.1016/j.cropro.2018.04.012.

Ariyanti M, Yahya S, Murtilaksono K, Suwarto, Siregar HH. 2014. Potential use of Nephrolepis biserrata as cover crop under mature oil palm plantation. Proceeding The 3rd International Conference on Multidisciplinary Research. Universitas Islam Sumatera Utara, Medan. [Indonesian]

Ariyanti M, Yahya S, Murtilaksono K, Suwarto, Siregar HH. 2015. Study of the growth of Nephrolepis biserrata Kuntze and its utilizationas cover crop under mature oil palm plantation. Intl J Sci Basic Appl Res 19 (1): 325-333.

Ariyanti M, Yahya S, Murtilaksono K, Suwarto, Siregar HH. 2016 Nephrolepis biserrata: gulma pakis sebagai tanaman penutup tanah di perkebunan kelapa sawit menghasilkan. Prosiding Seminar Nasional dan Kongres Perhimpunan Agronomi Indonesia 2016: 1007-1015. [Indonesian]

Asbur Y, Purwaningrum Y, Ariyanti M. 2015. Growth and nutrient balance of Asystasia gangetica (L.) T. Anderson as cover crop for mature oil palm (Elaeis guineensis Jacq.) plantations Chilean. J Agric Res 78: 486-494. DOI: 10.4067/S0718-58392018000400486

Asbur Y, Rambe RDH, Purwaningrum Y, Kusbiantoro D. 2018. Potensi beberapa gulma sebagai tanaman penutup tanah di perkebunan kelapa sawit menghasilkan. J Penelitian Kelapa Sawit 26 (3): 113-128. [Indonesian]

Asbur Y, Yahya S, Murtilaksono K, Sudradjat, Sutarta ES. 2016. The roles of Asystasia gangetica (L.) T. Anderson and ridge terrace in reducing soil erosion and nutrient losses in oil palm plantation in South Lampung, Indonesia. J Trop Crop Sci 3 (2): 49-55.

Bationo A, Kihara J, Vanlauwe B, Waswa B, Kimetu J. 2006. Soil organic carbon dynamics, functions, and management in West African agroecosystems. Agriculture Systems. Elsevier Applied Science Publishers Ltd., New York.

BKPM [Badan Koordinasi Penanaman Modal]. 2017. Regional superior commodities. http: //regionalinvestment.bkpm.go.id/newsipid/id/commodityarea.php?ia= $11 \& \mathrm{ic}=2$ [Indonesian]

Brown S, Gaston G. 1996. Estimates of Biomass Density for Tropical Forest. In: Levine JS (ed..). Biomass Burning and Global Change 1: 133-139. MIT Press, Cambridge, UK.

Directorate General of Estate Crops. 2017. Indonesian plantation statistics 2015-2017: the oil palm. Direktorat Jenderal Perkebunan, Kementerian Pertanian, Jakarta. [Indonesian]

Evrizal R. 2003. Pembibitan dan penanaman Arachis pintoi sebagai penutup tanah di kebun. J Agrotropika 8: 1-5. [Indonesian]

Fageria NK, Moreira A. 2011.The role of mineral nutrition on root growth of crop plants. In: Sparks DL (ed.). Advances in Agronomy, Vol. 110, Academic Press, Burlington.

Follett RF, Kimble JM, Pruessner EG, Samson-Liebig S, Waltman S. 2009. Soil Organic Carbon Stocks with Depth and Land Use at Various U.S. Sites. Chapter 3 In: Lal R, Follett RF (eds.). Soil Carbon Sequestration and the Greenhouse Effect. Soil Science Special Publication 57. John Wiley and Sons, New York.

Hartatik W. 2007. Thitonia diversifolia sumber pupukhijau. Warta Penelitian dan Pengembangan Pertanian 29 (5): 3-5. [Indonesian]

Haryantini BA, Santoso M. 2001. Pertumbuhan dan hasil cabai merah (Capsicum annum) pada andisol yang diberi mikoriza, pupuk fosfor dan zat pengatur tumbuh. Biosain 1 (3): 50-57. [Indonesian]

Heviaa GG, DE Buschiazzoa, EN Heppera. 2003. Organic matter in size fractions of soils of semiarid Argentina: Effects of climate, soil texture and management. Geoderma 116: 265-277.

Hikmat A. 2005. Biomass estimation, carbon storage and energy content of three virgin jung reserves in Peninsular Malaysia. Media Konservasi 10 (2): 1-8.

Hou R, Li ZOY, Tyler DD, Li F, Wilson GF. 2012. Effect of tillage and residue management on soil organic carbon and total nitrogen in the North China Plain. Soil Sci Soc Am J 76: 230-240.

IPCC [Intergovernmental Panel on Climate Change]. 1997. Revised 1996 IPCC Guidelines for National Greenhouse Gas Inventories-Workbook (Volume 2). https: //www.ipcc-nggip.iges.or.jp/public/gl/invs5c.html.

Islam KR, Weil RR. 2000. Soil quality indicator properties in MidAtlantic Soils as influenced by conservation management. J Soil Water Cons 55 (1): 69-78.

Junedi H, Myrna N, Fathia E. 2015. Peningkatan kemantapan agregat tanah pada ultisol melalui aplikasi ara sungsang (Asystasia gangetica (L.) T. Anders.). Prosiding Seminar Nasional Lahan Suboptimal 2015, Palembang 8-9 Oktober 2015. [Indonesian]

Junedi H. 2014. Pengaruh arasungsang (Asystasia gangetica (L.) T. Anders.) terhadap kadar air tersedia dan hasil kacang tanah pada ultisol. Prosiding Seminar Nasional Lahan Suboptimal 2014, Palembang 26-27 September 2014. [Indonesian]

Kaye J, Finney D, White C, Bradley B, Schipanski M, Alonso-Ayuso M. 2019. Managing nitrogen through cover crop species selection in the U.S. mid-Atlantic. PLoS ONE 14 (4): e0215448. DOI: 10.1371/journal.pone.0215448.

Kruidhof HM, Bastian L, Kropff MJ. 2009. Cover crop residue management for optimizing weed control. Plant Soil 318: 169-184. DOI 10.1007/s11104-008-9827-6.

Landriscini MR, Galantini JA, Duval ME, Capurro JE. 2019. Nitrogen balance in a plant-soil system under different cover crop-soybean 
cropping in Argentina. Appl Soil Ecol 133: 124-131. DOI: 10.1016/j.apsoil.2018.10.005.

Lasco RD. 2002. Forest carbon budgets in Southeast Asia following harvesting and land cover change. In: Impacts of land use Change on the Terrestrial Carbon Cycle in the Asian Pacific Region. Science in China 45: 76-86.

Liu Z, Shao M, Wang Y. 2011. Effect of environmental factors on regional soil organic carbon stock across the losses plateau region, China. Agric Ecosyst Environ 142: 184-194.

Maswar, Haridjaja O, Sabiham S, van Noordwijk M. 2011. Cadangan, kehilangan, dan akumulasi karbon pada perkebunan kelapa sawit di lahan gambut tropika. J Solum 8 (1): 1-10. DOI: 10.25077/js.8.1.110.2011 [Indonesian]

Maswar. 2009. Kecepatan dekomposisi biomassa dan akumulasi karbon pada konversi lahan gambut menjadi perkebunan kelapa sawit. Prosiding dan Lokakarya Nasional Inovasi Sumberdaya Lahan. Buku II: Teknologi Konservasi, Pemupukan, dan Biologi Tanah. Balai Besar Penelitian dan Pengembangan Sumberdaya Lahan Pertanian. Badan Penelitian dan Pengembangan Pertanian, Kementerian Pertanian, Jakarta. [Indonesian]

Odharva B, Beekrumb S, Akuala U, Baijnathc H. 2007. Preliminary assessment of nutritional leafy vegetables in Kwa Zulu-Natal, South Africa. J Food Compos Anal 20: 430-435.

Ohkura T, Yokoi Y, Imai H. 2003. Variations in soil organic carbon in Japanese arable lands. p273-280. In: Smith CAS (ed.) Soil Organic Carbon and Agriculture: Developing Indicators for Policy Analyses. Proceedings of an OECD expert meeting, Ottawa Canada.

Purba A, Rahutomo S. 2000. Introduksi kacangan penutup tanah alternatif Arachis pintoi pada areal kelapa sawit belum menghasilkan. Warta Pusat Penelitian Kelapa Sawit 8: 63-67. [Indonesian]

Putra ETS, Simatupang AF, Supriyatna, Waluyo S, Indradewa D.2012. The growth of one year-old oil palms intercropped with soybean and groundnut. J Agric Sci 4 (5): 169-180.

Quideau SA, Chadwick, Benesi A, Graham RC, Anderson MA. 2001. A direct link between forest vegetation type and soil organic matter composition. Geoderma 104: 41-60.

Robert M. 2001. Soil Carbon Sequestration for Improved Land Management. Food and Agriculture Organization (FAO) of the United Nations, Rome.
Ruddiman W. 2007. Losses of soil carbon plows, plagues, and petroleum: how humans took control of climate. Princeton University Press, Princeton, NJ.

Rusdiana O, Fakuara Y, Kusmana C, Hidayat Y. 2000. Respon Pertumbuhan Akar Tanaman Sengon (Paraserienthes falcataria) Terhadap Kepadatan dan Kandungan Air Tanah Podsolik Merah Kuning. Jurnal Manajemen Hutan Tropika 11 (2): 43-53. [Indonesian]

Samedani B, Juraimi AS, Anwar MP, Rafii MY, Sheikh Awadz SH, Anuar AR. 2013. Competitive Interaction of Axonopus compressus and Asystasia gangetica under contrasting sunlight intensity. Sci World J. DOI: 10.1155/2013/308646.

Satriawan H, Fuady Z. 2014. Teknologi Konservasi Tanah dan Air. Deepublish, Yogyakarta. [Indonesian]

Satriawan H, Fuady Z. 2019. Analysis of weed vegetation in immature and mature oil palm plantations. Biodiversitas 20: 3292-3298. DOI: 10.13057/biodiv/d201123

Shofiyati R, Las I, Agus F. 2010. Indonesian Soil Data Base and Predicted Stock of Soil Carbon. Proc. of Int. Workshop on Evaluation and Sustainable Management of Soil Carbon Sequestration in Asian Countries, Bogor, Indonesia.

Sugirahayu L, Rusdiana O. 2011. Perbandingan simpanan karbon pada beberapa penutupan lahan di Kabupaten Paser, Kalimantan Timur berdasarkan sifat fisik dan sifat kimia tanahnya. Jurnal Silvikultur Tropika 2 (3): 149-155. [Indonesian]

Sulistiyanto Y, Rieley JO, Limin SH. 2005. Laju dekomposisi dan pelepasan hara dari serasah dari dua sub-tipe hutan rawa gambut di Kalimantan Tengah. Jurnal Manajemen Hutan Tropika 9 (2): 1-14. [Indonesian]

Suryana, Chozin MA, Guntoro D. 2019. Species identification for cover crop on mature oil palm plantation. J Agron Indonesia 47 (3): 305311. DOI: 10.24831 /jai.v47i3.26980.

Tarnocai C, Canadell JG, Schuur EAG, Kuhry P, Mazhitova G, Zimov S. 2009. Soil organic carbon pools in the northern circumpolar permafrost region. Global Biogeochemical Cycles 23 (2): 1-11.

Yahya S. 2020. Natural resources-based integrated agricultural system for the sustainable plantation industry. IOP Conf Ser Earth Environ Sci 418: 012001. DOI: 10.1088/1755-1315/418/1/012001. 